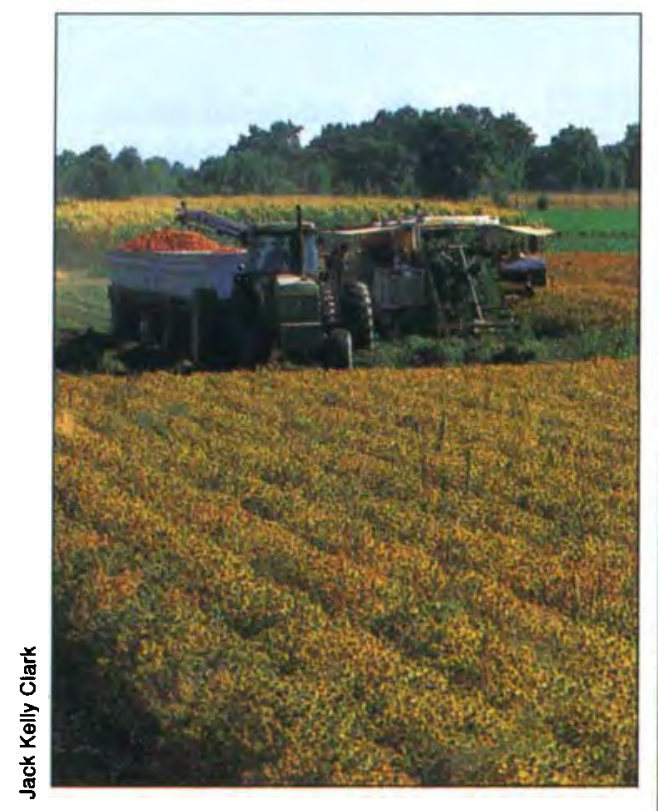

The 20-acre main experiment compared conventional, low-input and organic management using a 4-year, five-crop rotation of processing tomatoes, safflower, corn and wheat followed by double-cropped dry beans. Processing tomatoes, shown being mechanically harvested, were the key cash crop of the rotation.

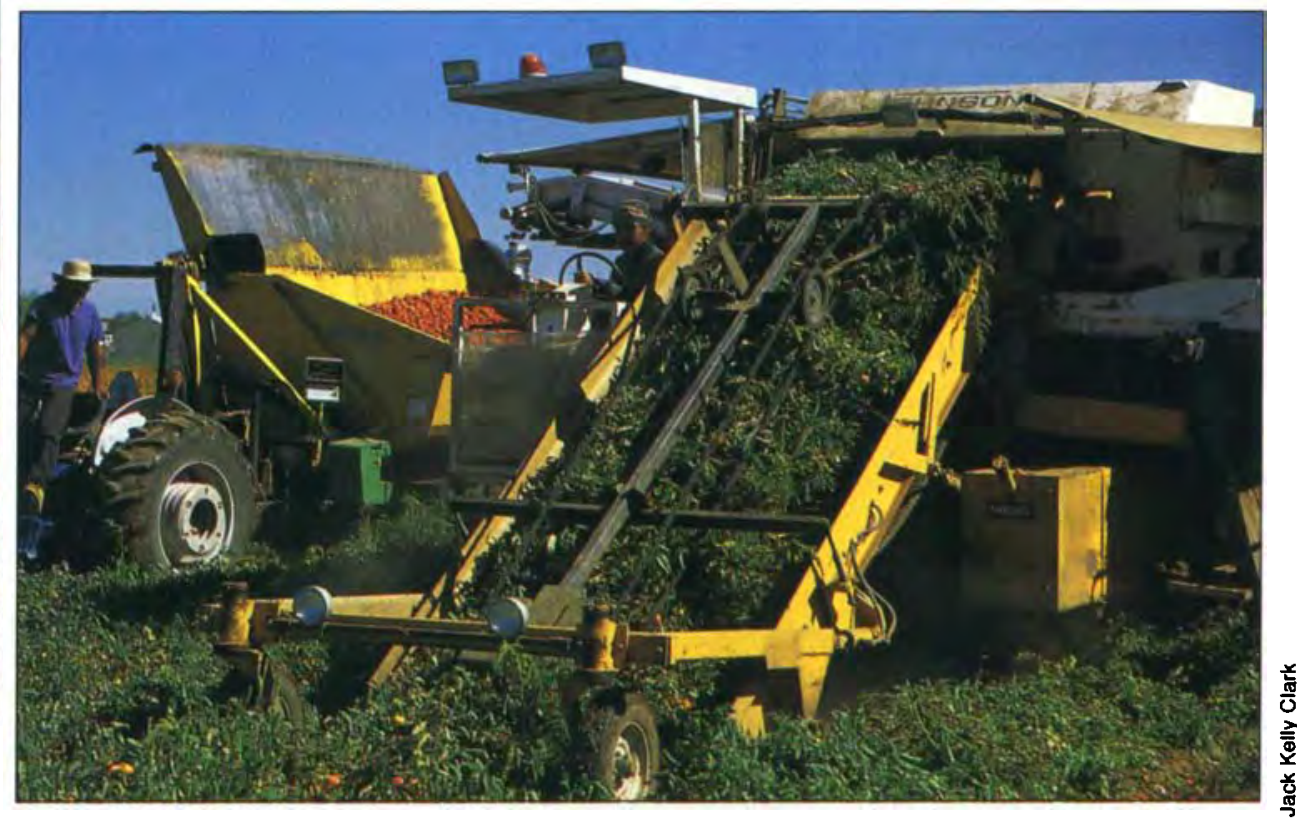

\title{
Conventional, low-input and organic farming systems compared
}

\author{
Steven R. Temple $\square$ Oscar A. Somasco $\square$ Mary Kirk $\square$ Diana Friedman
}

\begin{abstract}
Cover-crop nitrogen supply and weed management were the most important challenges facing lowinput and organic farming systems when compared to conventional systems in the first 4 years of the Sustainable Agriculture Farming Systems project at UC Davis. Cover-crop timing and management using appropriate equipment were important for the success of transitional systems. The participation of local farmers ensured that optimal agricultural practices were used to manage all farming systems. Researchers regularly consulted grower-cooperators to determine "best farmer practices" of conventional, low-input and organic farming systems.
\end{abstract}

Steadily growing public concerns about pesticides, food safety, environmental quality, groundwater contamination, dependency on finite supplies of fossil fuels and soil and water conservation were underscored by publication of the National Research Council's 1989 book, Alternative Agriculture. Following publication, the U.S. agricultural community vigorously debated how relevant and representative the report had been. Questions surrounded the examples used by the NRC to compare the sustainability of farming systems with differing amounts of nonrenewable purchased inputs. In 1988 a group of farmers and UC researchers met at UC Davis to plan a large interdisciplinary project with the primary objective of comparing conventional, low-input, and organic farming systems with respect to the following factors:
1. The abundance and diversity of weed, pathogen, arthropod and nematode populations.

2. Differences in soil biology, physical and chemical properties and water relations.

3. Crop growth, yield and quality.

4. Economic viability.

As a corollary objective, the project was to evaluate known and novel farming practices that showed potential to reduce dependence on nonrenewable resources. Results from these studies would be distributed widely in an effort to facilitate a dialog about the adoption of more sustainable farming practices. Here we report results from the first 4 years of this 12-year project.

Although some features of this research are similar to work already reported or in progress at the Rodale Research Institute in Pennsylvania, and efforts in Maryland, Virginia, 
South Dakota, Nebraska, Colorado and Wisconsin, the combination of a Mediterranean climate, a relatively long (4-year, five-crop) rotation, and management of each system using "best farmer practices" makes this effort unique (see box, below).

\section{Experimental design}

The 20-acre main experiment compared results from farming a 4-year, five-crop rotation using conventional, low-input and organic management of processing tomatoes, safflower, corn and wheat followed by doublecropped dry beans (table 1). Due to inadequate alternatives for weed management and nitrogen fertilization of wheat for the organic and low-input treatments, a mixture of oats and vetch was substituted for wheat in those two systems, following corn and before double-cropped common beans. In addition to the five cash crops, the lowinput and organic systems utilized nitrogen-fixing legume cover crops during the winter-spring season preceding tomatoes, safflower and corn.

The experiment was designed to run for two cycles of the crop rotation, after which future directions would be determined. Crop production was initiated late in 1988 on 1/3-acre plots replicated four times for each crop by system entry point of the rotation. Only the center third of each plot was used for yield measurements, to minimize border effects.

The economic analysis of the four systems and their respective crops was pivotal to the interpretation of project results. Costs and benefits of cultural practices were discussed at biweekly meetings with conventional and organic farmers, who emphasized the importance of tomatoes (and especially the higher-priced early-season tomatoes) on the overall profitability and equitable management of the different systems (for details, see page 35). Farmers were polled when poor performance of a crop required a cost/ benefit analysis for destroying that crop and deciding to replant, the same or a different crop, or to leave the ground fallow.

In addition to the 2.0 acres occupied by crops in the main experiment, an 8 -

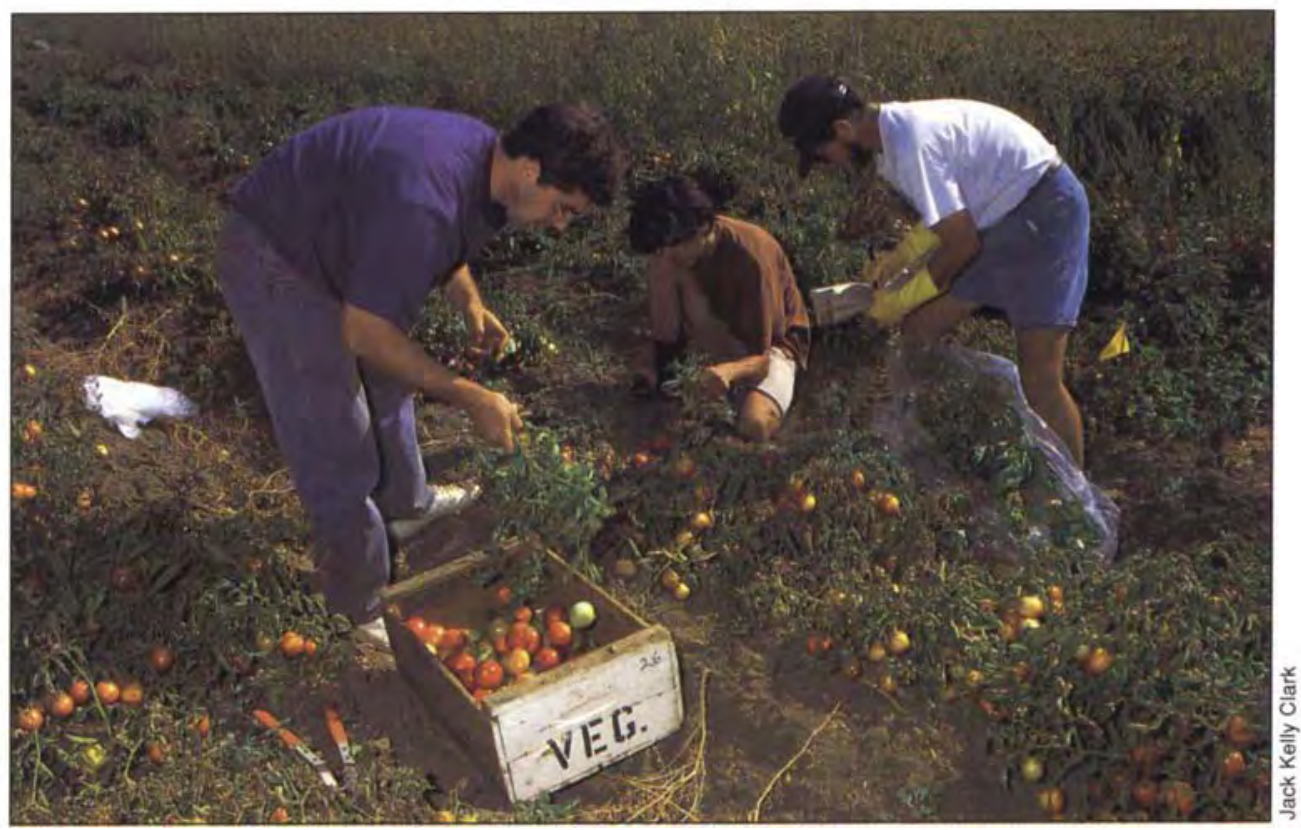

In addition to machine harvests, tomatoes were hand harvested to verify yield data.

\section{Definitions of Farming Systems Treatments}

The four farming systems all consisted of "best farmer practices" identified in the operation of progressive and economically efficient row-crop farms in the lower Sacramento Valley. Thus pest "scouting" and management based on IPM economic thresholds is a feature of all systems. Inputs, including water and sources of nitrogen fertilizer, were carefully monitored and judiciously managed to enhance the economic profitability of each system. Cooperating growers were regularly consulted for operational decisions.

"Best farmer practices." Management of each of the four systems had its inherent requirements for appropriate field machinery and timely operational decisions that responded to weather and the biotic challenges of farming. A group of grower-cooperators were regularly consulted on key farming decisions for all systems. For example, we discussed the benefits of field equipment operations, the practicality of preirrigating ground prior to fall planting or the wisdom of providing supplemental irrigation to winter crops in each system.

Conventional 4-year. The 4-year rotation used inorganic fertilizers, chemical weed control, Integrated Pest
Management-based insect and disease control, and irrigation and tillage practices common among successful rowcrop farmers in the Yolo County area.

Conventional 2-year. The 2-year rotation alternated wheat and processing tomatoes. Thit has been suggested for farming businesses seeking to maximize short-term economic returns by increasing the frequency of tomato harvests. The other three systems, all consisted of 4-year, five-crop rotations.

Low-input. Low-input maximized use of nitrogen-fixing legume cover crops and modest rates of supplementary manure or inorganic fertilizers. This treatment also attempted to replace long-lived pre-emergence herbicides with shorter-lived postemergence weed control. Chemicals wereused sparingly, and only when the agronomic or economic stability of the system was jeopardized, and tillage reductions were sought.

Organic. Organic practices complied with regulations of California Certified Organic Farmers (CCOF), and were focused on use of cover crops, limited use of composted manures, mechanical weed control, and insect management using biological control and infrequent applications of CCOF-approved products. 
acre companion area contained larger (1.2-acre) blocks planted to the same five crops and managed like the lowinput system. Better cover crop options, as well as improved practices for weed management, tillage and crop nutrition, were evaluated at the companion site by project researchers with a broad array of disciplinary interests.

\section{Soil sampling, pest monitoring}

Extensive soil samples were taken in order to monitor and recommend appropriate farming practices for crop nutrition, as well as to document changes in soil physical properties, microbiological activity, nematode and pathogen populations, and concentrations of toxic chemicals (for details, see
TABLE 1. Crops grown for each of the different rotation entry points in four farming systems

\begin{tabular}{|c|c|c|c|c|}
\hline System & 1989 & 1990 & 1991 & 1992 \\
\hline Conv 4 & tomato & safflower & corn & wheat/bean \\
\hline Conv 4 & wheat & tomato & safflower & corn \\
\hline Conv 4 & corn & wheat/bean & tomato & safflower \\
\hline Conv 4 & safflower & corn & wheat/bean & tomato \\
\hline Conv 2 & tomato & wheat & tomato & wheat \\
\hline Conv 2 & wheat & tomato & wheat & tomato \\
\hline Low-input & tomato & vetch/safflower & vetch/corn & oat-vetch/bean \\
\hline Low-input & lupin & vetch/tomato & vetch/safflower & vetch/corn \\
\hline Low-input & corn & lupin*/bean & vetch/tomato & safflower"/bean \\
\hline Low-input & safflower & vetch/corn & oat-vetch/bean & vetch/tomato \\
\hline Organic & tomato & vetch/safflower & vetch/corn & oat-vetch/bean \\
\hline Organic & lupin"/barley & vetch $+/$ tomato & vetch/safflower & vetch/corn \\
\hline Organic & corn & lupin $\% /$ bean & vetch/tomato & safflower $r^{*} /$ bean \\
\hline Organic & safflower & vetch/corn & oat-vetch/bean & vetch/tomato \\
\hline
\end{tabular}

-A combination of poor crop stand and slow development (compared to weed competitors) resulted in disking under of crop and weed biomass as a green manure.

†Vetch cover crop was disked under and replanted late, resulting in a poor production of biomass.

TABLE 2. Crop yields for four farming systems during the first rotation cycle (1989-1992)

\begin{tabular}{|c|c|c|c|c|c|}
\hline \multirow{2}{*}{ Crop } & \multicolumn{4}{|c|}{ System } & \multirow{2}{*}{$\begin{array}{c}\text { Yolo County } \\
\text { average }\end{array}$} \\
\hline & Organic & Low-input & Conv 4-yr & Conv 2-yr & \\
\hline \multicolumn{6}{|c|}{ Tomato (tons/acre) } \\
\hline-1989 & $24.50 \mathrm{~b}^{*}$ & $30.92 a$ & $34.33 \mathrm{a}$ & $34.2 \mathrm{a}$ & 30.2 \\
\hline 1990 & $30.70 \mathrm{c}$ & $36.28 \mathrm{~b}$ & $36.82 \mathrm{ab}$ & $39.6 \mathrm{a}$ & 28.8 \\
\hline 1991 & $28.20 \mathrm{c}$ & $34.85 \mathrm{~b}$ & $45.58 \mathrm{a}$ & $37.4 \mathrm{~b}$ & 30.5 \\
\hline 1992 & 42.66 & 42.87 & 47.70 & 41.3 & 33.8 \\
\hline \multicolumn{6}{|c|}{ Safflower (Ib/acre) } \\
\hline 1989 & $1,358 \mathrm{~b}$ & $1,343 \mathrm{~b}$ & $2,058 \mathrm{a}$ & - & 2,320 \\
\hline 1990 & 2,070 & 2,350 & 2,160 & - & 2,100 \\
\hline 1991 & 1,990 & 1,879 & 2,155 & - & 1,740 \\
\hline $1992 \dagger$ & - & - & 2,575 & - & 1,920 \\
\hline \multicolumn{6}{|c|}{ Corn (tons/acre) } \\
\hline 1989 & 4.18 & 5.21 & 5.08 & - & 4.51 \\
\hline 1990 & 5.20 & 5.00 & 4.91 & - & 4.87 \\
\hline 1991 & $4.07 \mathrm{~b}$ & $4.09 \mathrm{~b}$ & $5.06 \mathrm{a}$ & - & 4.59 \\
\hline 1992 & $4.92 \mathrm{~b}$ & $5.92 \mathrm{a}$ & $4.76 \mathrm{~b}$ & - & 4.90 \\
\hline \multicolumn{6}{|c|}{ Wheat (lb/acre) } \\
\hline 1989 & - & - & $4,507 \mathrm{~b}$ & $4,916 \mathrm{a}$ & 5,200 \\
\hline 1990 & - & - & 4,615 & 4,961 & 4,660 \\
\hline 1991 & - & - & 5,273 & 5,485 & 5,380 \\
\hline 1992 & - & - & 4,694 & 4,498 & 4,440 \\
\hline \multicolumn{6}{|c|}{ Beans (Ib/acre) $\ddagger$} \\
\hline 1990 & Y 2,218 a & Y $2,330 \mathrm{a}$ & S $1,934 \mathrm{~b}$ & - & 1,980 \\
\hline 1991 & RK 1,592 & RK 1,457 & RK 1,140 & - & 1,780 \\
\hline 1992 & $Y 2,830$ & $Y 2,716$ & Y 2,442 & - & 1,780 \\
\hline
\end{tabular}

-Differences between means within a horizontal row followed by the same letter are not statistically significant at the $5 \%$ level.

†Organic and low-input safflower in 1992 were plowed under and pink beans were planted, yielding 2,193 and $2,273 \mathrm{lbs} / \mathrm{acre}$, respectively.

‡Bean varieties: $Y=$ Yolano pink; $S=$ Sutter pink; $R K=$ Red kidney pp. 20-26 and 27-33). Crop growth and development were compared by recording stand establishment, plantgrowth parameters, yield and quality. Because processing tomatoes were the key cash crop of the rotation, tomato plant growth parameters such as flower and fruit numbers, plant height, foliage and fruit weight were monitored in greater detail, and tomato petiole nutrient analyses were conducted at three specific stages during crop growth. Insects and diseases were monitored, using recommended IPM scouting practices, to facilitate timely crop management decisions and to explain losses in yield and quality. Weeds were sampled and sorted by species at harvest, and sometimes at key opportunities during competition with crops. The center third of each plot was machine harvested with commercial-sized equipment. A hand harvest, stratified to representatively sample each plot, was done in the area adjacent to the machine-harvested strip for crops where equipment problems resulted in large harvest losses.

\section{Yields evaluated}

Yields from the first 4-year rotation cycle are presented in table 2 . Average yields for most crops in the conventional 4-year system were close to Yolo County averages, suggesting that management of these semicommercialsized plots was comparable to that of local growers. The crop-by-crop analysis that follows highlights some of the apparent reasons for yield differences observed during the first 4-year rotation, including those most frequently cited by farmers seeking to reduce conventional inputs.

Tomato. Tomato yields are important because of the economic role the crop plays in whole-farm sustainability (see pp. 34-42). Therefore the significantly lower yields of low-input tomatoes for 1991, and of organic tomatoes for 1989, 1990 and 1991, are a source of concern, indicating that these systems may not be economically viable during the transition phase. In 1989 , we observed reduced vegetative growth in the low-input and organic tomatoes, as well as a higher incidence 
of fruit damaged by insects. The 1990 organic tomatoes yielded $20 \%$ less than the low-input and conventional tomatoes. Data from soil sampling and plant-growth analyses suggest the lower yield was largely due to inadequate nitrogen supply from the vetch cover crop that preceded tomatoes in the rotation (see pp. 20-26). Higher populations of pigweed, a preferred host of the armyworm, apparently worsened pest-management problems for the organic tomatoes.

A conventional tomato yield of 45.6 tons per acre in 1991 was 50\% higher than the Yolo County average and significantly greater than yields registered for low-input and organic treatments ( 34.9 and 28.2 tons per acre, respectively). These advantages may be attributed to differences in plant nutrition, as evidenced by petiole $\mathrm{NO}_{3}$ levels during growth and early fruiting, and to a greater abundance of weeds in the low-input and organic treatments competing for limited resources (table 3).

Concern was raised that we wouldn't be able to take advantage of market price incentives for early tomatoes if we delayed direct seeding of all tomato plots until May 9 to accommodate growth and incorporation of the vetch cover crop in the organic and low-input systems. Following the 1991 tomato harvest, the project group, including growers and farm advisors, met to develop a strategy to improve plant nutrition and weed management in the low-input and organic treatments. We decided to use transplants in the low-input and organic tomatoes in 1992, thereby permitting greater nitrogen fixation and biomass production by allowing the preceding vetch cover crop to grow longer without compromising the demand for early tomato deliveries. Weed control and water management were also facilitated by transplanting. Further, nitrogen fertility in the organic treatment was enhanced by the addition of 1.5 tons per acre of composted chicken manure (3\% nitrogen) at transplanting and two foliar applications of fish emulsion and seaweed kelp fertilizers during crop growth. The low-input treatment received 9.6 pounds per acre of nitrogen as a starter at transplanting and 30 pounds per acre of nitrogen as sidedressed ammonium nitrate. The conventional 2- and 4-year treatments received 6 and 9 pounds per acre, respectively, of starter nitrogen and 120 pounds each of sidedressed nitrogen.

There were no significant differences among tomato yields for 1992. The conventional systems were direct seeded March 28 and the organic and low-input systems were transplanted April 14. As in previous seasons, conventional yields were well above reported county averages; the absence of significant differences is due almost entirely to increases in yield for the low-input and organic treatments. The utility of these measures to improve tomato yields must still be confirmed in subsequent years.

Corn. The performance of corn over treatments and seasons appears to be more consistent than that of tomatoes. Significant yield differences were only observed in 1991 (favoring conventional) and 1992 (favoring low-input). The 1991 corn yields of the organic and low-input systems were adversely affected by inadequate incorporation of the 3,000-pound vetch cover crop that preceded the corn (see tables 4 and 5, and pp. 20-26). In 1992 the yield advantage of the low-input over the conventional corn did not appear to be a result of nitrogen nutrition (table 4). Examining results from 1992, growers suggested instead that the 60 -inch bed system used for conventional corn (two rows per bed) was less adequate than the single-row 30 -inch beds used for organic and low-input corn, due principally to differences in the moisture available to portions of conventional corn root systems that are oriented toward the furrow or toward the

\begin{tabular}{|c|c|c|c|c|c|c|}
\hline \multirow[b]{3}{*}{ System } & \multicolumn{6}{|c|}{$\begin{array}{l}\text { TABLE 3. Petiole } \mathrm{NO}_{3} \text { and weed biomass crop yield for tomatoes } \\
\text { in four farming systems for the } 1991 \text { and } 1992 \text { crop seasons }\end{array}$} \\
\hline & \multicolumn{2}{|c|}{$\begin{array}{c}\text { Petiole } \mathrm{NO}_{3} \\
\text { (ppm @ early bloom) }\end{array}$} & \multicolumn{2}{|c|}{$\begin{array}{l}\text { Weed biomass } \\
\text { (Ib/acre @ harvest)* }\end{array}$} & \multicolumn{2}{|c|}{$\begin{array}{c}\text { Yield } \\
\text { (tons/acre) }\end{array}$} \\
\hline & 1991 & 1992 & 1991 & 1992 & 1991 & 1992 \\
\hline Organic & $1,530 \mathrm{bt}$ & $6,560 \mathrm{~b}$ & 46 & $162 a$ & $28.2 \mathrm{c}$ & 42.7 \\
\hline Low-input & $1,800 \mathrm{~b}$ & $12,220 \mathrm{a}$ & 40 & $212 a$ & $34.9 \mathrm{~b}$ & 42.9 \\
\hline Conv 4-yr & 4,270 a & $15,470 \mathrm{a}$ & 0 & $16 b$ & $45.6 \mathrm{a}$ & 47.8 \\
\hline Conv 2-yr & $4,100 \mathrm{a}$ & $15,150 \mathrm{a}$ & 0 & $44 \mathrm{~b}$ & $37.4 \mathrm{~b}$ & 41.3 \\
\hline
\end{tabular}

-Dry weight.

†Differences between means within a vertical column, followed by the same letter, are not statistically significant at the $5 \%$ level.

TABLE 4. Percent $\mathbf{N}$ in ear leaf, yield, and weed competition for field corn grown under three farming systems during the 1991 and 1992 crop seasons

\begin{tabular}{|c|c|c|c|c|c|c|}
\hline & \multicolumn{2}{|c|}{$\begin{array}{c}\text { Percent } \mathrm{N} \\
\text { (ear leaf @ silking) }\end{array}$} & \multicolumn{2}{|c|}{$\begin{array}{c}\text { Yield } \\
\text { (tons/acre) }\end{array}$} & \multicolumn{2}{|c|}{$\begin{array}{c}\text { Weed biomass } \\
\text { (Ib/acre @ harvest) }\end{array}$} \\
\hline & 1991 & 1992 & 1991 & 1992 & 1991 & 1992 \\
\hline Organic & $2.4^{*}$ & $2.4 \mathrm{~b}$ & $4.07 b$ & $4.92 \mathrm{~b}$ & 93 & 744 a \\
\hline Low-input & 2.4 & $2.8 \mathrm{a}$ & $4.09 b$ & $5.92 \mathrm{a}$ & 46 & $33 \mathrm{~b}$ \\
\hline Conventional & 3.0 & $2.8 \mathrm{a}$ & $5.06 \mathrm{a}$ & $4.76 \mathrm{~b}$ & 1 & $20 \mathrm{~b}$ \\
\hline
\end{tabular}

-Differences between means within a vertical column, followed by the same letter, are not statistically significant at the $5 \%$ level.

TABLE 5. Yield of cover crop dry matter of Lana woollypod vetch planted in two farming systems for 1991 and 1992

\begin{tabular}{|c|c|c|c|c|}
\hline \multirow[b]{2}{*}{ Crop } & \multicolumn{2}{|c|}{ Organic } & \multicolumn{2}{|c|}{ Low-input } \\
\hline & 1991 & 1992 & 1991 & 1992 \\
\hline & \multicolumn{4}{|c|}{ 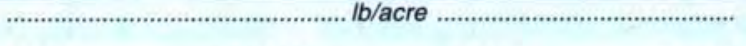 } \\
\hline Vetch/tomato & 3,913 & $3,209^{*}$ & 3,582 & $3,392^{*}$ \\
\hline Vetch/corn & 3,846 & 4,644 & 2,877 & 4,503 \\
\hline Vetch/safflower & 3,277 & - & 2,448 & - \\
\hline \multicolumn{5}{|l|}{ Oat-vetch seed $\dagger$} \\
\hline Oat819 & 402 & 1,630 & - & - \\
\hline Vetch & 964 & 257 & 463 & - \\
\hline
\end{tabular}

*1992 dry matter values include biomass contributions of vetch, volunteer oats and weeds at time of plowdown.

†Values are for seed yield (lb/acre) in the rotation spot following corn and before double-cropped dry beans. 


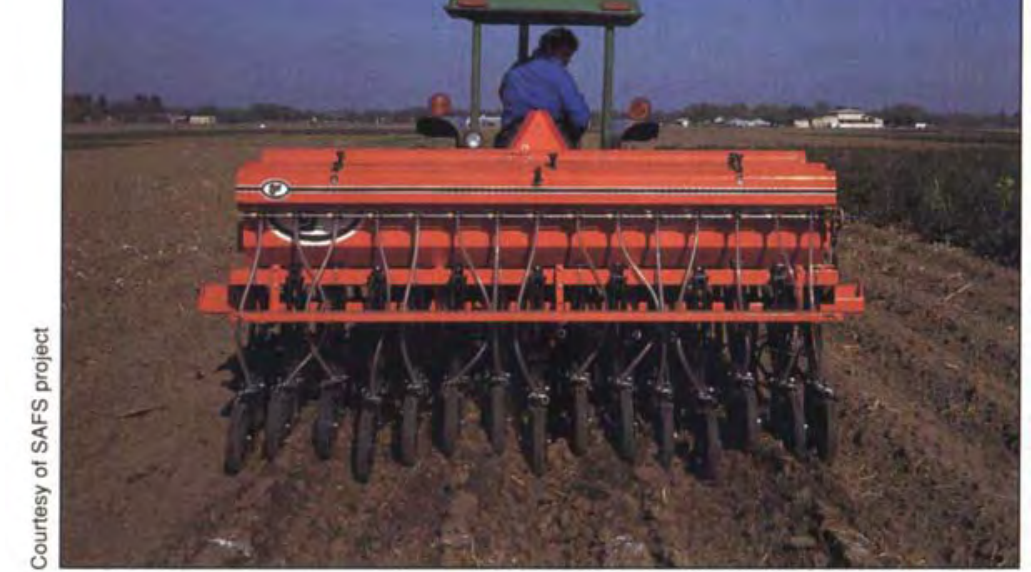

In the low-Input and organic plots, cover crops such as lupin and vetch were drilled into residue using a no-tIll range drill.

inside of the 60-inch bed. Future corn crops will have 30 -inch rows in all systems.

Yield differences in 1992 between organic and low-input corn, which were both supplied with nitrogen by a similar crop of vetch (table 5), are best explained by the effects of weed compestition for nitrogen, light and water (see table 4 and pp. 27-33). The timing of cover crop incorporation and subsequent planting of corn requires clear weather and machinery to perform field operations that allow establishment of the corn without supplemental moisture prior to crop emergence. Failing this, the timely application of 2,4-D to low-input corn in 1992 resulted in a large yield advantage for that system over organic corn, for which no comparable management tool was available.

Safflower. Safflower was included in the rotation mostly for its demonstrated flexibility under different levels of management, and for its potential as a spring (largely rain-fed) crop that can be planted after killing winter weeds and well ahead of summer weeds. Only in 1989 were conventional safflower yields statistically superior to organic and low-input yields (table 2). However, in early 1992, organic and low-input safflower performed very poorly, and these crops were ultimately disked under and re- planted with dry beans in order to retain the economic competitiveness of those two systems.

The most serious reservation about the utility of safflower in lowinput/organic systems rests not in its yield potential. Like corn, safflower challenges the grower to skillfully manage the preceding nitrogen-fixing cover crop according to soil and weather conditions at the time of planting. The first 4 years of this study were characterized by little or no fall rain, so that most of the legume covers did not germinate until winter and put on little biomass before March, which is the accepted date for planting safflower. To obtain adequate cover crop growth, safflower would not have been planted until about April 15, which is too late for the crop. As a result, 1989-1992 winter cover crops were hard to accommodate with safflower planting and resulted in lower yields or crop failure (severe weed pressure). In 1992-1993, new options, such as the use of fall/winter legume mixes after tomato harvest, were evaluated in the companion area in the search for alternate management strategies (data not reported). Fall incorporation of animal manures favors winter weed growth and nitrogen loss, while February/March incorporation of covers and manures and planting safflower to moisture requires at least two weeks of favorable weather. Conventional planting in beds prepared in the fall and managed by means of winter chemical fallow are less subject to the vagaries of weather. We are still evaluating the methods we began for low-input and organic systems in 1992-1993.

Beans. Dry beans are a logical rotation crop for transitions toward lowinput and organic farming systems. Manipulation of moisture and fertility should favor this crop over many of its weedy summer competitors, and excellent organic and pesticide-free bean crops have been produced by local growers and in the companion area of this project on a 1.2-acre parcel. The 1990 low-input and organic bean yields were significantly better than the conventional yield. The higher yields of the fuller-season pink variety, following the failure of grain lupin in the low-input and organic treatments, represented only a partial compensation for the loss of a winter cash crop, which was followed by a shorterseason, double-crop pink variety in the conventional system. In the 1991 and 1992 seasons, and using the same variety in all systems, the advantages of low-input and organic dry beans over the conventional treatment were not statistically significant. Beans performed very well in 1992 as a "catch" crop to compensate for the safflower loss in the organic and low-input systems, where the beans yielded 2,193 and 2,273 pounds per acre, respectively.

Winter crops. Wheat performed in the conventional 2- and 4-year systems as expected, with yields near local averages. Results from winter legumes and legume-grass mixtures in the organic and low-input systems are less consistent and reflect challenges reported by local growers and farm advisors during the planning stages of the project. The 1989, low-input lupin crop, planted on open ground in October 1988, yielded a respectable 2,169 pounds per acre, and with better harvesting equipment more of the 3,620 pounds per acre, hand-harvested yield would have been realized. But in the absence of fall rains and without either a protective corn residue or herbicides, the organic lupin plots had late and uneven germination, competed very poorly with winter weeds, and were disked under the following spring to plant a barley catch crop that competed favorably with spring weeds and yielded 1,823 pounds per acre. In 1990 the low-input and organic lupin were drilled into corn stubble using a no-till range drill. Without fall moisture, germination was poor and late, so that winter-spring weed competition was severe, and the lupin was disked under before a 
threatening amount of weed seed matured.

A decision was made in 1990 to drop winter lupin in the low-input and organic systems and to substitute an oat-vetch mixture as a green manure, green chop haylage or seed crop in the rotation spot before doublecropped beans. We continue to evaluate lupin as an alternative winter legume, but limiting fall moisture and strong competition from winter weeds may limit the crop's utility to only the low-input system. The 1991 vetch cover crop produced between 3,000 and 3,600 pounds per acre of dry matter and an estimated 125 to 155 pounds per acre of nitrogen prior to planting tomatoes, corn and safflower. The 1991 oat-vetch mixture yielded well in both systems (table 5), and was followed by double-cropped kidney beans. In 1992 the flexibility of the oatvetch crop permitted the harvest of the low-input system as a 17.1 tons per acre green chop cash crop on May 1, while the organic oat-vetch was harvested on June 9 as a seed crop.

\section{Comparing the systems}

The absence of complete symmetry in management practices (varieties, planting dates, tillage practices, seeded versus transplanted, and actual units of nitrogen fertilizer) complicates the task of making specific comparisons of crop-system combinations. These differences are especially difficult to interpret where key pieces of agricultural equipment were not available to perform precise cultural operations in a timely manner. This was especially true in the management of "new" crops like lupin and the oatvetch seed crop, and particularly for the organic and (to a lesser extent) the low-input systems, where fewer crop-saving practices are known and approved. The result was a higher incidence of failed crops. Growercooperators recommended that we incorporate these crops as green manure and replant with a catch crop (barley, dry beans) as a farmer would to reduce the negative impact of expended capital and lost crops on the overall economic viability of the rotation. The development and utilization of implements to better manage cover crops and nonchemical weed control are cited by farmers as components of the "learning curve" that transition demands of growers and researchers. Economic criteria discussed by Klonsky et al. (pp. 34-42) have been heavily weighted by the farming systems group in evaluating the adequacy of crops and production practices used during the first 4-year cycle. Prices received, and especially the premiums received for certified organic commodities, have a powerful influence.

From the standpoint of crop performance and yield, it appears that a rotation of processing tomatoes, safflower, field corn and wheat or winter legume, followed by double-cropped dry beans, is a good crop rotation on which to make systems comparisons. The use of nitrogen-fixing winter cover crops for green manure and as seed crops has merit, but also resulted in crop management challenges that required "best farmer" experience and flexibility to work within the constraints imposed by time and weather. The late winter/early spring management of cover crops, including residue management, seedbed preparation, supplemental manuring and the retention of sufficient soil moisture to germinate tomatoes, corn and safflower with little or no herbicide has become a central research theme for continuing studies in the large companion plots adjacent to the main experiment.

The interdisciplinary group is focusing on several key issues as the project enters the second rotation cycle. These include identifying the best cover crops for each system/season combination and observing phenomena that have an impact on soil fertility and plant nutrition, particularly the season-long monitoring of cover-crop-derived nitrogen fertility, crop growth and yield. The long-term implications of weed control, as well as the related demand for creative management and appropriate equipment, are critical. Some cultural practices of the low-input and organic systems have a relatively narrow window of opportunity in which repetitive or slow operations lead to a constant race with the weather. The project group continues to look for scale-neutral management systems that can be used by large and small growers alike.

Conclusions about the preferable crop with which to enter the rotation are still premature. The attractive premiums offered for organically grown tomatoes, and regulations that specify a minimum of 3 years without pesticides prior to certification, suggest that field corn would be the best entry point, but pest control (and especially weed management) implications of this choice must be considered. Choices will also depend on the grower's economic situation and a consideration of the wide range of costs and returns for the five cash crops in the rotation. The challenges of managing winter cover and grain legume cash crops without herbicides (organic), or with short-lived, postemergence herbicides (low-input), are at least partially offset by the opportunities to plant or replant catch crops, such as spring barley after lupin and pink beans after safflower in this study.

Perhaps the most interesting result to date is the productivity of a group process in which farmers and farm advisors have joined campus-based researchers as full partners in planning, conducting and interpreting results from the study. It is apparent that the project could not approach "best farmer" systems comparisons without significant grower input, and that there is significant value in the interdisciplinary learning that takes place as the group seeks ways to improve and compare each of the four systems.

S.R. Temple is Extension Agronomist, UC Davis; O.A. Somasco was Research Manager and is now Agronomist, Argentina; M.Kirk was Research Manager and is now Horticulturist, Ithaca, NY; and D.

Friedman is Agronomist and Research manager of the SAFS project, UC Davis.

The project would like to thank the $D A N R$ analytical lab for conducting all soil and plant analyses reported in this study. The project is supported by grants from USDA-SARE and UC-SAREP and by contributions from a large group of agribusiness interests and growers. 